\title{
Lead and Carbon Monoxide Effects on Human Atrial Action Potential. In Silico Study
}

\author{
Catalina Tobón ${ }^{1}$, Diana C. Pachajoa ${ }^{2}$, Juan P. Ugarte $^{3}$, Andrés Orozco-Duque ${ }^{2}$, Javier Saiz ${ }^{4}$ \\ ${ }^{1}$ MATBIOM, Facultad de Ciencias Básicas, Universidad de Medellín, Medellín, Colombia \\ ${ }^{2} \mathrm{GI}{ }^{2} \mathrm{~B}$, Instituto Tecnológico Metropolitano, Medellín, Colombia \\ ${ }^{3}$ Facultad de Ingenierías, Universidad de San Buenaventura, Medellín, Colombia \\ ${ }^{4} \mathrm{CI}^{2} \mathrm{~B}$, Universitat Politècnica de València, Valencia, España
}

\begin{abstract}
Exposure to air pollutants like lead $\left(\mathrm{Pb}^{++}\right)$and carbon monoxide (CO), promotes the occurrence of cardiovascular diseases. Experimental studies have shown that $\mathrm{Pb}^{++}$and $\mathrm{CO}$ block the L-type calcium channels, decreasing the calcium current $\left(I_{C a L}\right)$ and the action potential duration (APD), favoring the initiation of atrial arrhythmias.

Our goal is to study the effects of $\mathrm{Pb}^{++}$and $\mathrm{CO}$ at different concentrations, on $I_{C a L}$ and action potential using computational simulation. For this, we developed mathematical models of the air pollutants effects on the atrial L-type calcium channel and they were incorporated in a mathematical model of human atrial cell and in a $2 D$ model of atrial tissue.

Our results suggest that the $\mathrm{Pb}^{++}$and $\mathrm{CO}$ block the $I_{\text {CaL }}$ current in a fraction that increases as the concentration increases, generating an APD shortening. The combined effect of both air pollutants generated an APD shortening and a stable rotor, which is considered as a pro-arrhythmic effect. These results are consistent with experimental studies.

In silico studies may contribute to a better understanding of the mechanisms by which air pollutants have unhealthy effects on cardiac system.
\end{abstract}

\section{Introduction}

Air pollution is defined as the presence in the atmosphere of one or more substances in sufficient quantity to produce health alterations. Air pollution causes 4.3 million premature deaths annually [1]. In 2010, the economic cost of health impacts of air pollution in developing countries was around USD 1.7 billion [1].

Lead $\left(\mathrm{Pb}^{++}\right)$is a toxic agent that can exert adverse health effects in humans. According to the United States Environment Protection Agency (EPA), the $\mathrm{Pb}^{++}$is one of the most dangerous air pollutants, affecting multiple human body systems [2]. In general, more than 143.000 people die every year due to illnesses related to $\mathrm{Pb}^{++}$[3].
Carbon monoxide (CO) is a toxic gas, from incomplete combustion. When people breath, the $\mathrm{CO}$ binds to hemoglobin and is significantly retained within the blood reducing the amount of oxygen that it can transport [4].

Exposure to these air pollutants contributes to cardiovascular diseases [5]. Epidemiological studies have reported effects such as heart failure, generation of cardiac arrhythmias and decreased heart rate variability [3,5-11]. Experimental studies have shown that the $\mathrm{Pb}^{++}$ blocks the L-type calcium channels [12]. A decrease in Ltype calcium current $\left(\mathrm{I}_{\mathrm{CaL}}\right)$ is an important mechanism that favors the generation of atrial arrhythmias [13]. Recently, it has been shown that chronic exposure to $\mathrm{CO}$ promotes a pathological phenotype of cardiomyocytes, where remodeling leads to an important reduction of the action potential duration (APD) in atrial myocardium increasing the risk of arrhythmias $[9,10]$ and ischemia [14]. This study aims to assess the effects of the $\mathrm{Pb}^{++}$and $\mathrm{CO}$ at different concentrations on human atrial action potential, using computational simulation.

\section{Methods}

\subsection{Human atrial cell model}

The Courtemanche-Ramirez-Nattel-Kneller $[15,16]$ membrane formalism was implemented to simulate the electrical activity of human atrial cell. A $0.005 \mu \mathrm{M}$ of acetylcholine concentration was simulated. The transmembrane voltage $\left(V_{m}\right)$ is given by:

$$
C_{m} \frac{d V_{m}}{d t}+I_{\text {ion }}+I_{s t}=0
$$

where $C_{m}$ is the membrane capacitance $(100 \mathrm{pF}), I_{\text {ion }}$ is the total membrane current, and $I_{s t}$ is the external stimulus current. The model is considered under normal electrophysiological conditions.

\subsection{Model of $\mathrm{Pb}^{++}$and $\mathrm{CO}$ effects on $\mathrm{I}_{\mathrm{CaL}}$}

We developed concentration dependent equations to 
simulate the $\mathrm{Pb}^{++}$and $\mathrm{CO}$ effects on $\mathrm{I}_{\mathrm{CaL}}$ and they were included in the $\mathrm{I}_{\mathrm{CaL}}$ equation as blocking factors.

To develop a basic model of the $\mathrm{Pb}^{++}$effect on $\mathrm{I}_{\mathrm{CaL}}$, we used the steady state fraction of blockade $\left(b_{P b}\right)$. In this model the kinetics of the channel would be considered unchanged in the presence of the $\mathrm{Pb}^{++}$. Hill equation has been used to fit the concentration-response relationship for ligand block. It describes the fraction of the macromolecule saturated by ligand as a function of the ligand concentration; it is used for determining the degree of cooperativeness of the ligand binding with the receptor:

$$
b_{P b}=\frac{1}{\left[1+\frac{I C_{50}}{D_{P b}}\right]^{h}},
$$

where $\mathrm{IC}_{50}$ is the half maximal inhibitory concentration for the current block by $\mathrm{Pb}^{++}, D_{P b}$ is the $\mathrm{Pb}^{++}$ concentration. A Hill coefficient $(h)$ of 1 indicates completely independent binding. For the $\mathrm{IC}_{50}$ to block $\mathrm{I}_{\mathrm{CaL}}$, we used $152 \mathrm{nM}$, this value was found in ventricular myocytes [12]. There are no reported values of the $\mathrm{IC}_{50}$ for blocking channels by $\mathrm{Pb}^{++}$on atrial myocytes.

Based on an experimental study [14], we established a relationship between the $\mathrm{CO}$ concentration and the APD decrease. This study attribute the APD decrease to a blockage of the $\mathrm{I}_{\mathrm{CaL}}$ current; therefore, we developed a basic model of the $\mathrm{CO}$ effect on the $\mathrm{I}_{\mathrm{CaL}}$ current. The blocking factor $\left(b_{C O}\right)$ of the $\mathrm{I}_{\mathrm{CaL}}$ current by $\mathrm{CO}$ is dependent on the concentration of $\mathrm{CO}\left(D_{C O}\right)$ and has a lineal behavior. This equation was introduced in the $\mathrm{I}_{\mathrm{CaL}}$ equation of the cell model, and it was adjusted to obtain APD reductions approximately equal to those observed experimentally. Following, the equations to calculate $b_{\mathrm{CO}}$ and $\mathrm{I}_{\mathrm{CaL}}$ are given by:

$$
\begin{gathered}
b_{C O}=0.0002 D_{C O}+0.0827 \\
I_{C a L}=\left(1-b_{C O}\right)\left(1-b_{P b}\right) g_{C a L} d f f_{C a}\left(V_{m}-65\right),
\end{gathered}
$$

where $g_{C a L}$ is the maximum conductance of $\mathrm{I}_{\mathrm{CaL}}, d$ is the activation gate, $f$ is the voltage-dependent inactivation gate, $f_{C a}$ is the calcium-dependent inactivation gate and 65 is the value of equilibrium potential for $\mathrm{I}_{\mathrm{CaL}}$.

\subsection{D model of human atrial tissue}

A 2D model of human atrial tissue was developed, which consists of a $6 \times 6 \mathrm{~cm}$ domain. It was discretized at a spatial resolution of $312.5 \mu \mathrm{m}$, to form a mesh of $192 \mathrm{x}$ 192 elements.

\subsection{Electrical propagation model}

In the $2 \mathrm{D}$ model, the propagation in cardiac tissue defined by the monodomain model of electrical propagation is described by the following reactiondiffusion equation:

$$
\frac{1}{s_{v}} \nabla \cdot\left(D \nabla V_{m}\right)=C_{m} \frac{\partial V_{m}}{\partial t}+I_{\text {ion }}+I_{s t},
$$

where $S_{v}$ is the surface/volume ratio and $D$ is the conductivity tensor. The equation was solved using a semi-spectral scheme [17]. The tissue was considered isotropic. A conductivity of $0.4 \mathrm{~S} / \mathrm{cm}$ was assigned in order to obtain a conduction velocity of $62.5 \mathrm{~cm} / \mathrm{s}$.

\subsection{Simulation protocol}

We implemented the unicellular models to simulate the sinus rhythm under physiological conditions, using the Cellular Open Resource public CellML OpenCOR ${ }^{\circledR}$ software. Forward Euler method with a time step of 0.001 ms was implemented to solve the equations.

A train of 10 stimuli was applied at a basic cycle length of $1000 \mathrm{~ms} . \mathrm{Pb}^{++}$and $\mathrm{CO}$ concentrations from 0 to $300 \mathrm{nM}$ and from 0 to $1000 \mathrm{uM}$ were implemented, respectively. The APD at $90 \%$ of the repolarization $\left(\mathrm{APD}_{90}\right), \mathrm{I}_{\mathrm{CaL}}$ current and the resting membrane potential (RMP) were measured on the 10th beat using a program developed in MATLAB ${ }^{\circledR}$ software.

The S1-S2 cross-field protocol was applied in the 2D model (rectangular pulses of $2 \mathrm{~ms}$ duration and $6 \mathrm{~mA}$ amplitude). The $\mathrm{S} 1$ stimulus was plane and was applied at the left boundary of the model. The S2 stimulus was rectangular $(3 \mathrm{~cm} \mathrm{x} 3 \mathrm{~cm})$ and was applied $167 \mathrm{~ms}$ after $\mathrm{S} 1$ at a corner of the model. The simulation ran for 2 seconds.

\section{Results}

The $\mathrm{I}_{\mathrm{CaL}}$ current without $\mathrm{Pb}^{++}$or $\mathrm{CO}$ effects shows a peak of $-454 \mathrm{pA}$, the current remains active during the plateau phase of action potential. The $\mathrm{APD}_{90}$ has a value of $211 \mathrm{~ms}$ under control conditions.

First we applied different $\mathrm{Pb}^{++}$concentrations. As the $\mathrm{Pb}^{++}$concentration increases, $\mathrm{I}_{\mathrm{CaL}}$ downregulation is observed, which causes an APD shortening and loss of plateau phase. When the highest $\mathrm{Pb}^{++}$concentration was applied $(300 \mathrm{nM})$, the $\mathrm{I}_{\mathrm{CaL}}$ peak decreased $61 \%(-179 \mathrm{pA})$ and the $\mathrm{APD}_{90}$ reached a value of $113 \mathrm{~ms}$, which indicates a decrease of $47 \%$.

When different CO concentrations were applied, as the $\mathrm{CO}$ concentration increases, $\mathrm{I}_{\mathrm{CaL}}$ downregulation is also observed, which causes an APD shortening and loss of plateau phase. When the highest $\mathrm{CO}$ concentration was applied $(1000 \mu \mathrm{M})$, the $\mathrm{I}_{\mathrm{CaL}}$ peak decreased $22 \%(-356$ $\mathrm{pA})$ and the $\mathrm{APD}_{90}$ reached a value of $151 \mathrm{~ms}$, which indicates a decrease of $28 \%$.

When we applied both air pollutants, the $\mathrm{Pb}^{++}$and $\mathrm{CO}$ 
blockade the $\mathrm{I}_{\mathrm{CaL}}$ current in a fraction that increases as the concentration increases, resulting in $\mathrm{APD}_{90}$ shortening. As the $\mathrm{Pb}^{++}$and $\mathrm{CO}$ concentrations increases, $\mathrm{I}_{\mathrm{CaL}}$ downregulation is observed, which causes the APD shortening and loss of plateau phase of the action potential. When the highest $\mathrm{Pb}^{++}$and $\mathrm{CO}$ concentrations were applied (300 $\mathrm{nM}$ and $1000 \mathrm{uM}$, respectively), the $\mathrm{I}_{\mathrm{CaL}}$ peak decreased by $71 \%(-130 \mathrm{pA})$ and the $\mathrm{APD}_{90}$ decreased by $51 \%(104 \mathrm{~ms})$. The RMP did not show significant changes (-83 $\mathrm{mV}$ approximately).

Table 1 shows the $\mathrm{APD}_{90}$ decreasing values in function of the different $\mathrm{Pb}^{++}$and $\mathrm{CO}$ concentrations.

Table 1. $\mathrm{APD}_{90}$ values at different $\mathrm{Pb}^{++}$and $\mathrm{CO}$ concentrations.

\begin{tabular}{ccc}
\hline$\left[\mathrm{Pb}^{++}\right]$ & {$[\mathrm{CO}]$} & $\mathrm{APD}_{90}$ \\
\hline $0 \mathrm{nM}$ & $0 \mu \mathrm{M}$ & 211 \\
$60 \mathrm{nM}$ & $200 \mu \mathrm{M}$ & 139 \\
$120 \mathrm{nM}$ & $400 \mu \mathrm{M}$ & 123 \\
$180 \mathrm{nM}$ & $600 \mu \mathrm{M}$ & 115 \\
$240 \mathrm{nM}$ & $800 \mu \mathrm{M}$ & 110 \\
$300 \mathrm{nM}$ & $1000 \mu \mathrm{M}$ & 104 \\
\hline
\end{tabular}

Figure 1 shows the effects of different $\mathrm{Pb}^{++}$and $\mathrm{CO}$ concentrations on $\mathrm{I}_{\mathrm{CaL}}$ current and atrial action potential.
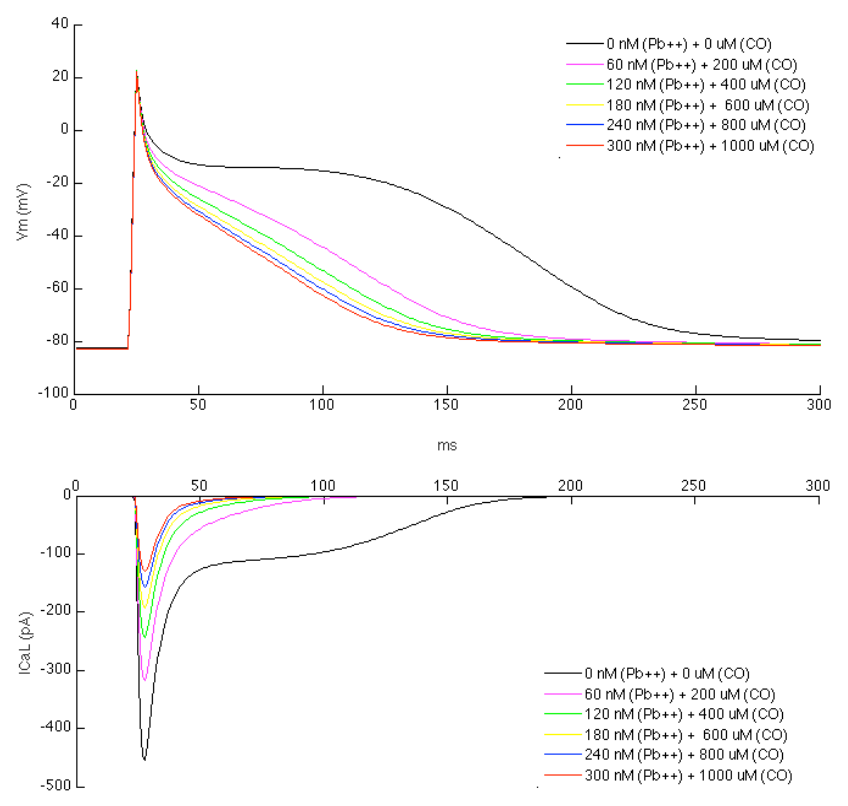

Figure 1. Atrial action potential and $\mathrm{I}_{\mathrm{CaL}}$ current at different $\mathrm{Pb}^{++}$and $\mathrm{CO}$ concentrations.

When S1-S2 cross-field protocol was applied in the 2D model without $\mathrm{Pb}^{++}$or $\mathrm{CO}$ effects, a rotor was not generated. However, when the highest $\mathrm{Pb}^{++}$and $\mathrm{CO}$ concentrations were applied $(300 \mathrm{nM}$ and $1000 \mathrm{uM}$, respectively), a stable rotor was observed (Figure 2), showing the pro-arrhythmic effect of the pollutants in the atrial tissue.

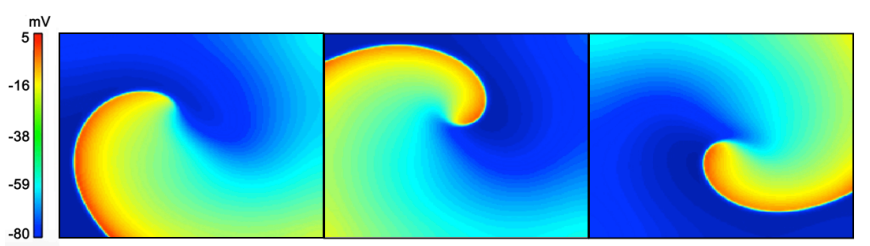

Figure 2. Rotor generated by applying the highest $\mathrm{Pb}^{++}$ and $\mathrm{CO}$ concentrations.

\section{Discussion}

Our results showed that $\mathrm{Pb}^{++}$blocks the $\mathrm{I}_{\mathrm{CaL}}$ current in a fraction greater as the concentration increases, prolonging its action in time, which results in an APD shortening as was demonstrated experimentally [12]. This analysis is consistent with an experimental study in ventricle myocytes of rats [12], where the $\mathrm{Pb}^{++}$blocked the L-type calcium channels, however, its mechanism is not well explained. There are not in silico studies of $\mathrm{Pb}^{++}$ effects on human atrial action potential.

Our results also showed that $\mathrm{CO}$ blocks the $\mathrm{I}_{\mathrm{CaL}}$ current, in a fraction greater as the $\mathrm{CO}$ concentration increases. These results are consistent with experimental studies. A study in rats [14] showed that CO leads to an important reduction of the APD in atrial myocardium, as well as a significant acceleration of the sinus rhythm and reduction in the force of contraction. Our results are consistent with these studies, as soon as the concentration of CO increases, the APD shortening is observed. There are not in silico studies of $\mathrm{CO}$ effects on human atrial action potential.

When we simulated the combined effects on $\mathrm{I}_{\mathrm{CaL}}$ of the two air pollutants, $\mathrm{CO}$ and $\mathrm{Pb}^{++}$at different concentrations, our results showed a significant APD decrease in a fraction greater as the concentrations increase, which is a severe pro-arrhythmic effect. Our results in a human atrial cell model are in agreement with results from non-human in vitro and in vivo studies.

Clinical studies have shown that air pollution increases the risk of cardiovascular disease mortality by $76 \%$ [18]; deaths are related to ischemia, arrhythmias and heart failure mainly [19-21]. Sufficient evidence has been found to conclude that a brief exposure to high levels of pollutants increases the cardiac patients mortality. Likewise, it has been shown that prolonged exposures reduce people's life expectancy by several years, and hospital admissions due to cardiovascular diseases increase with high pollutants concentrations [22]. Recent studies have been able to demonstrate a higher probability of occurrence of cardiac arrhythmias after exposure to air pollutants, concluding that air pollution is an acute "trigger" of these arrhythmias [23]. Despite the existence 
of studies on the effects of air pollutants on the cardiovascular system in the literature, the mechanisms underlying the effects of acute and chronic exposure to these agents on the heart have not been well established.

\section{Conclusion}

Our results show pro-arrhythmic effects of $\mathrm{Pb}^{++}$and $\mathrm{CO}$ on expressed through shortening of APD, during normal electrophysiological conditions. In silico studies may contribute to a better understanding of the mechanisms by which air pollutants have unhealthy effects on cardiac tissue, promoting cardiac diseases as arrhythmias.

\section{Acknowledgements}

This work was supported by the project with UdeM code 882 .

\section{References}

[1] OECD. The cost of air pollution. Health impacts of road transport. OECD Publishing, 2014:1-80.

[2] U.S. EPA. National Ambient Air Quality Standards (NAAQS) | Air and Radiation | US EPA. US Environ Prot Agency, Off Air Qual Plan Stand. 2012;(4):2014-5.

[3] WHO. Lead poisoning and health [Internet]. World Health Organization; 2016. Available from: http://www.who.int/mediacentre/factsheets/fs379/en/

[4] Henry CR, Satran D, Lindgren B, Adkinson C, Nicholson CI, Henry TD. Myocardial Injury and Long-term Mortality Following Moderate to Severe Carbon Monoxide Poisoning. Am Med Assoc. 2006;295(4):398-402.

[5] Bhatnagar A. Cardiovascular pathophysiology of environmental pollutants. Am J Physiol Heart Circ Physiol. 2004;286(2):H479-85.

[6] Prentice R, Kopp S. Cardiotoxicity of lead at various perfusate calcium concentrations: Functional and metabolic responses of the perfused rat heart. Toxicol Appl Pharmacol. 1985;81:491-501.

[7] Ansari MA, Maayah ZH, Bakheet SA, El-Kadi AO, Korashy $\mathrm{H}$. The role of aryl hydrocarbon receptor signaling pathway in cardiotoxicity of acute lead intoxication in vivo and in vitro rat model. Toxicology. 2013;306:40-9.

[8] Samoli E, Touloumi G, Schwartz J, Anderson HR, Schindler C, Forsberg B, et al. Short-Term Effects of Carbon Monoxide on Mortality: An Analysis within the APHEA Project. Environ Health Perspect. 2007;115(11):1578-83.

[9] Dales R. Ambient Carbon Monoxide May Influence Heart Rate Variability in Subjects With Coronary Artery Disease. Occup Env Med. 2004;46(12):1217-21.

[10] Simkhovich BZ, Kleinman MT, Kloner RA. Air Pollution and Cardiovascular Injury. Epidemiology, Toxicology, and Mechanisms. Journal of the American College of Cardiology. 2008;52(9):719-26.

[11] U.S. EPA. Integrated Science Assessment (ISA) for Lead (Final Report, Jul 2013). Washington; 2013.
[12] Bernal J, Lee J, Cribbs LL, Perez-reyes E. Full Reversal of $\mathrm{Pb}++$ Block of L-Type $\mathrm{Ca}++$ Channels Requires Treatment with Heavy Metal Antidotes1. 1997;282(1):172-80.

[13] Dinanian S, Boixel C, Juin C, Hulot J-S, Coulombe A, Rücker-Martin C, et al. Downregulation of the calcium current in human right atrial myocytes from patients in sinus rhythm but with a high risk of atrial fibrillation. Eur Heart J. 2008;29(9):1190-7.

[14] Abramochkin DV, Haertdinov NN, Porokhnya MV, Zefirov AL, Sitdikova GF. Carbon monoxide affects electrical and contractile activity of rat myocardium. J Biomed Sci. 2011;18(1):40.

[15] Courtemanche M, Ramirez R, Nattel S. Ionic targets for drug therapy and atrial fibrillation-induced electrical remodeling: insights from a mathematical model. Cardiovasc Res. 1999;42(2):477-89.

[16] Kneller J, Zou R, Vigmond EJ, Wang Z, Leon J, Nattel S. Cholinergic atrial fibrillation in a computer model of a twodimensional sheet of canine atrial cells with realistic ionic properties. Circ Res. 2002;90(9):E73-87.

[17] Ugarte JP, Tobón C, Orozco-Duque A, Andrade-Caicedo $\mathrm{H}$. Generation of fibrillatory dynamics in cardiac tissue: fractional diffusion as arrhythmogenic mechanism modelling tool. Applied Mathematical Sciences. 2017;11(13):637-50

[18] Miller KA, Siscovick DS, Sheppard L, Shepherd K, Sullivan JH, Anderson GL, et al. Long-term exposure to air pollution and incidence of cardiovascular events in women. N Engl J Med. 2007;356(5):447-58.

[19] Brook RD, Franklin B, Cascio W, Hong Y, Howard G, Lipsett $\mathrm{M}$, et al. Air pollution and cardiovascular disease: A statement for healthcare professionals from the expert panel on population and prevention science of the American Heart Association. Circulation. 2004;109(21):2655-71.

[20] Finkelstein M. Pollution-related mortality and educational level. JAMA. 2002;288(7):830.

[21] Pope CA, Burnett RT, Thun MJ, Calle EE, Krewski D, Ito $\mathrm{K}$, et al. Lung cancer, cardiopulmonary mortality, and longterm exposure to fine particulate air pollution. JAMA. 2002;287(9):1132-41.

[22] UNEP. UNEP Year Book 2014 emerging issues update. Air Pollution: World's Worst Environmental Health Risk. Nairobi: United Nations Environment Programme, Environment for Development; 2014.

[23] Link MS, Luttmann-Gibson H, Schwartz J, Mittleman MA, Wessler B, Gold DR, et al. Acute exposure to air pollution triggers atrial fibrillation. $\mathrm{J}$ Am Coll Cardiol. 2013;62(9):816-25.

Address for correspondence.

Catalina Tobón Zuluaga

Calle 4 \# 28 - 61, Medellín, Colombia

ctobon@udem.edu.co 